\title{
The Importance of Thoracic Tomography in Prognosis in Critical Covid 19 Patients
}

\section{Kritik Covid 19 Hastalarinda Toraks Tomografisinin Prognozdaki Önemi}

\author{
@Veysel Garani Soylu', @Öztürk Taşkın'1, @Ufuk Demir'1, @Yunus Yaşar² \\ 'Kastamonu Training and Research Hospital, Intensive Care Department, Kastamonu, Turkey \\ ${ }^{2}$ Kastamonu Training and Research Hospital, Radiology Department, Kastamonu, Turkey
}

\begin{abstract}
Aim: Computed tomography (CT) images of the chest are often used to support the diagnosis of COVID-19 and infectious diseases. This study aims to question the importance of specific chest CT results in predicting the prognosis of COVID-19 patients being followed up in the intensive care unit (ICU).
\end{abstract}

Material and Method: For this study, 20 critically ill patients whose RT-PCR tests were positive for COVID-19 were included. Mortality, invasive and non-invasive mechanical ventilator requirement, APACHE II scores and ICU staying days were compared chest CT scans with have poor prognosis results before admission to ICU.

Results: Critical patients who were followed up in the ICU due to COVID-19 disease with crazy paving pattern on chest CT images, it was concluded that there is a statistically significant requirement for invasive mechanical ventilation support during the ICU period $(p=0.04)$. We reported that all patients with pleural and pericardial effusion required invasive mechanical ventilation support. One of the chest CT results observed in critical COVID-19 patients In ICU is that the consolidation / ground glass opacity pattern> 1 may have a higher (about five-fold) mortality rate. Most of our critical COVID-19 patients who stayed in intensive care for a long time had a crazy paving pattern on chest $\mathrm{CT}$ images.

Conclusion: We believe that some results obtained from chest CT scans in COVID-19 disease may predict the prognosis of the patient during the intensive care period.

Keywords: Covid 19, thoracıc tomography, prognosıs

\section{Öz}

Amaç: Toraks bilgisayarlı tomografi (BT) görüntüleri sıklıkla COVID-19 ve bulaşıı hastalıkların teşhisini desteklemek için kullanılmaktadır. Bu çalışma, yoğun bakım ünitesinde (YBÜ) izlenen COVID-19 hastalarının prognozunu tahmin etmede spesifik göğüs BT sonuçlarının önemini sorgulamayı amaçlamaktadır.

Gereç ve Yöntem: Bu çalışmaya RT-PCR testleri COVID-19 için pozitif olan 20 kritik hasta dahil edildi. YBÜ'ye kabul edilmeden önce çekilen toraks BT taramalarında kötü prognoz sonuçlarl; mortalite, invazif ve non-invaziv mekanik ventilatör gereksinimi, APACHE II skorları ve YBÜ yatış günleri ile karşılaştıııldı.

Bulgular: Göğüs BT görüntülerinde kaldıım taşı paterni olan COVID-19 hastalığı nedeniyle YBÜ'de izlenen kritik hastalarda, YBÜ takibinde;invazif mekanik ventilasyon desteği gereksinimi istatistiksel olarak anlamlı bulundu ( $p=0.04)$. Plevral ve perikardiyal efüzyonu olan tüm hastaların invazif mekanik ventilasyon desteğine ihtiyacı oldu. Yoğun bakım ünitesinde kritik COVID-19 hastalarında gözlenen göğüs BT sonuçlarından olan, konsolidasyon / buzlu cam opasite paterninin> 1 olan hastalar daha yüksek (yaklaşık beş kat) ölüm oranına sahipti. Yoğun bakım yatı̧s süresi daha fazla olan hastalarda kaldııım taşı manzarası görünümü mevcuttu.

Sonuç: COVID-19 hastalığında göğüs BT taramalarından elde edilen bazı sonuçların yoğun bakım döneminde hastanın prognozunu öngörebileceğini düşünüyoruz.

Anahtar Kelimeler: Covid 19, toraks tomografisi, prognoz 


\section{INTRODUCTION}

In mid-December 2019, several cases of pneumonia of unknown origin appeared in certain hospitals in Wuhan City, Hubei Province, China. ${ }^{[1]}$ These cases of pneumonia were reported to be caused by coronavirus. ${ }^{[2]}$ The virus, which is the causative agent of pneumonia, was called SARS-CoV-2 and the disease that it caused was named Coronavirus Disease 2019 (COVID-19) by the World Health Organization (WHO) in February 2020.[3,4] SARS-CoV-2 belongs to $\beta$-coronavirus, a typical RNA virus. Usually, it is round- or oval-shaped with a diameter of 60-140 nm under an electron microscope. Its outer membrane has unique spikes of $\sim 9-12 \mathrm{~nm}$, similar to the Sun's corona. ${ }^{[2]}$ On March 11, 2020, WHO announced that the COVID-19 epidemic is a worldwide "pandemic". ${ }^{[4]}$

Note that COVID-19 is transmitted from person to person by respiratory droplets and contact. Similar to severe acute respiratory syndrome coronavirus (SARS-CoV) and Middle East respiratory syndrome coronavirus (MERS-CoV), the common clinical symptoms of patients with COVID-19 are fever, coughing, shortness of breath, and fatigue. ${ }^{[5]}$ Despite mild symptoms and good prognosis in most patients, it can cause serious diseases such as pneumonia, pulmonary edema, acute respiratory distress syndrome, multiple organ failure, and even death. ${ }^{[6,7]}$

Reverse transcription PCR (RT-PCR) is the most useful test worldwide for diagnosing COVID-19 disease; however, the positivity rate of RT-PCR is $30 \%-60 \% .{ }^{[8,9]}$ It is a fact that, along with RT-PCR test, chest CT results are useful for its diagnosis.

Clinical physicians, epidemiologists, virologists, and phylogeneticists are trying to control the pathogenesis of infection and the spread of COVID-19, while certain researchers are examining imaging models using chest radiography and computerized tomography (CT). For example, typical radiographical patterns that are seen in the chest $C T$ scans of almost all COVID-19 patients are ground glass opacity, multifocal irregular consolidation, and/or interstitial changes with peripheral distribution. ${ }^{[10,11]}$

CT was used for diagnosing the disease. ${ }^{[12]}$ To answer the question "Does computerized tomography provide insight about the prognosis of the disease?" current studies are still insufficient. In this study, therefore, we aimed to investigate the importance of CT in predicting the prognosis of COVID-19 patients during the intensive care process.

\section{MATERIAL AND METHOD}

Our study includes 20 critical COVID-19 patients who were followed up in the Covid intensive care unit of Kastamonu Training and Research Hospital and whose RT-qPCR tests conducted by the hospital laboratory tested positive between March 2020 and July 2020. There were no patients who previously performed lobectomy with lung surgery or patients with findings that could be superposed by COVID-19 disease findings in tomography images (interstitial lung disease, tuberculosis, etc.).
Ethics committee approval for the study was received from the Non-Invasive Clinical Research Ethics Committee of Zonguldak Bülent Ecevit University on 25 June 2020, with the decision numbered 2020/14.

Patient files were retrospectively reviewed. For each patient, data concerning duration of intensive care stay, requirement for invasive-noninvasive mechanical ventilator support, 28-day mortality, APACHE II score at the time of first admission to intensive care unit and non-contrast chest CT results taken within the last 24 $\mathrm{h}$ prior to admission to intensive care unit was recorded.

Chest CT images were retrospectively evaluated by a radiologist with six years of experience in thoracic radiology, using multiplanar reconstruction tools on CT images from a PACS workstation (Sisopacs, Sisoft). All scans were acquired using a 16-row multidetector scanner (Siemens Somatom Emotion 16, Erlangen, Germany). All images were obtained using the parameters $120 \mathrm{kVp}$, $150 \mathrm{Ma}, 1.5 \mathrm{~mm}$ collimation, $1.35: 1$ pitch, $512 \times 512$ reconstruction matrix and $1.0 \mathrm{~mm}$ slice thickness.

In recent studies, bad prognosis markers on chest CT images of critical COVID-19 patients with lung involvement have been determined to be CT score, presence of pleural/pericardial effusion, consolidation/ground glass pattern of $>1$, presence of COVID-19 evidence in the right upper and middle lobe of the lung, crazy-paving pattern, and linear opacity. Ct score was evaluated as quantitative measures. These markers were the results specified in the literature..$^{[6,13-16]}$

Statistical analysis was performed using SPSS (IBM Corp., Armonk, NY, USA). In terms of normality, the distribution of variables was assessed using the Kolmogorov-Smirnov test. Descriptive data were expressed as mean \pm standard deviation and lower and upper values were also specified. Normally distributed data containing continuous variables were then analyzed using Student's t test, and categorical variables were analyzed using the Chi-square test in which Fisher's exact test was used in the presence of frequency values of $<5$ in any cell in the cross table. Note that $p<0.05$ was considered to be statistically significant.

\section{RESULTS}

In this study, 20 critical COVID-19 patients were included. Note that $16(80 \%)$ patients were male and $4(20 \%)$ were female; the age range was between 37 and 87 . At least one comorbidity (DM, HT, etc.) was present in 17 patients (85\%) and APACHE II scores varied between 13 and 35. During their intensive care stay, 11 patients (55\%) died and 14 patients (70\%) required invasive mechanical ventilator support. Moreover, intensive care hospitalization of the patients was between 1 and 60 days, whereas the mean duration of stay was 13.25 days (Table 1 ).

According to the tomography results of the patients herein, there were nine patients (45\%) with linear opacity, 5 patients $(25 \%)$ with pleural and pericardial effusion, 8 patients (40\%) with crazy-paving pattern, 17 patients (85\%) with upper and middle lobe involvement of the right lung, and 7 patients (35\%) with consolidation/ground glass ratio of $>1$ (Figure 1). 


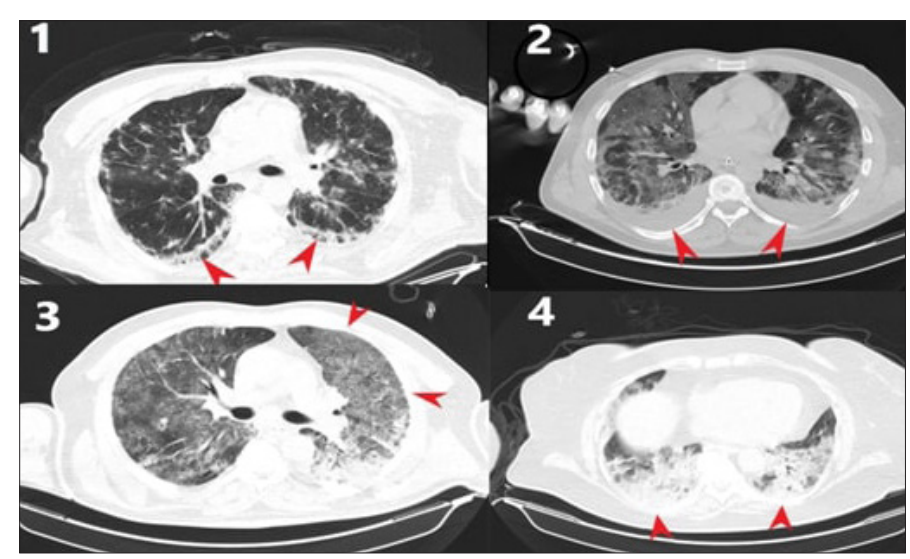

Figure 1. 1)Lineer opacity, 2)Pleural effusion, 3)Crazy-paving, 4)Consolidation

\begin{tabular}{|c|c|c|c|c|c|c|}
\hline sex & additional disease & age & $\begin{array}{c}\text { mv } \\
\text { need }\end{array}$ & mortal & $\begin{array}{l}\text { days } \\
\text { of icu } \\
\text { stay }\end{array}$ & $\begin{array}{l}\text { apache } \\
\text { ii }\end{array}$ \\
\hline M & $\mathrm{HF}$ & 37 & NIMV & - & 9 & 16 \\
\hline$M$ & COPD & 70 & IMV & + & 11 & 31 \\
\hline$M$ & LUNG CANCER & 61 & NIMV & - & 1 & 20 \\
\hline$M$ & $\mathrm{COPD}+\mathrm{HT}+\mathrm{DM}$ & 73 & IMV & + & 26 & 31 \\
\hline M & $\begin{array}{l}\text { LUNG } \\
\text { TRANSPLANTATION }\end{array}$ & 54 & IMV & + & 6 & 17 \\
\hline$M$ & HT & 59 & IMV & - & 26 & 16 \\
\hline $\mathrm{F}$ & $\mathrm{COPD}+\mathrm{HT}$ & 57 & NIMV & - & 1 & 14 \\
\hline M & $\mathrm{DM}+\mathrm{HT}$ & 59 & IMV & + & 19 & 20 \\
\hline $\mathrm{F}$ & $\mathrm{DM}+\mathrm{HT}+\mathrm{CKD}$ & 77 & IMV & + & 14 & 28 \\
\hline M & - & 45 & IMV & - & 14 & 14 \\
\hline M & CKD & 55 & NIMV & - & 4 & 24 \\
\hline M & COPD+DM & 80 & IMV & + & 4 & 33 \\
\hline $\mathrm{F}$ & BREAST CANCER $+\mathrm{HT}$ & 75 & IMV & + & 9 & 23 \\
\hline M & CVD & 87 & IMV & + & 3 & 35 \\
\hline M & - & 44 & IMV & + & 28 & 13 \\
\hline M & TESTICULARTM & 38 & IMV & + & 7 & 13 \\
\hline M & COPD & 77 & IMV & - & 60 & 21 \\
\hline $\mathrm{F}$ & $\mathrm{HT}+\mathrm{DM}+\mathrm{HF}$ & 74 & NIMV & - & 3 & 15 \\
\hline M & - & 86 & IMV & + & 9 & 33 \\
\hline $\mathrm{F}$ & DM & 75 & NIMV & - & 11 & 16 \\
\hline $\begin{array}{l}\text { ICU, in } \\
\text { obstr } \\
\text { diseas } \\
\text { invasi }\end{array}$ & $\begin{array}{l}\text { ive care unit; F,female; } M \text {, } \\
\text { epulmonary disease; ;T, } \\
\text { D, cerebrovasculer diseas } \\
\text { echanical ventilation }\end{array}$ & $\begin{array}{l}\mathrm{HF}, \mathrm{h} \\
\text { tensic }\end{array}$ & $\begin{array}{l}\text { ailure; CO } \\
\text { M, diabet }\end{array}$ & $\begin{array}{l}\text { chronic } \\
\text { ellitus; }\end{array}$ & chror & $\begin{array}{l}\text { idney } \\
\text { ition; IMV, }\end{array}$ \\
\hline
\end{tabular}

Their CT scores ranged between 2 and 33, and there were 14 patients (70\%) with a CT score of $<19.5$ (Table 2, Figure 2).

Critical COVID-19 patients with crazy-paving pattern on their CT images in the last $24 \mathrm{~h}$ prior to their admission to the intensive care unit were reported to have a statistically significant requirement for invasive mechanical ventilator during their stay in the ICU $(P=0.04)$. Although presence of pleural/pericardial effusion does not bring about a statistically significant difference in terms of the requirement for invasive mechanical ventilators, all of the patients with pleural and pericardial effusion were placed on IMV $(n=5)$. There was no statistically significant difference reported in other results of bad prognosis on chest $\mathrm{CT}$ in terms of requirement for IMV during the intensive care stay.
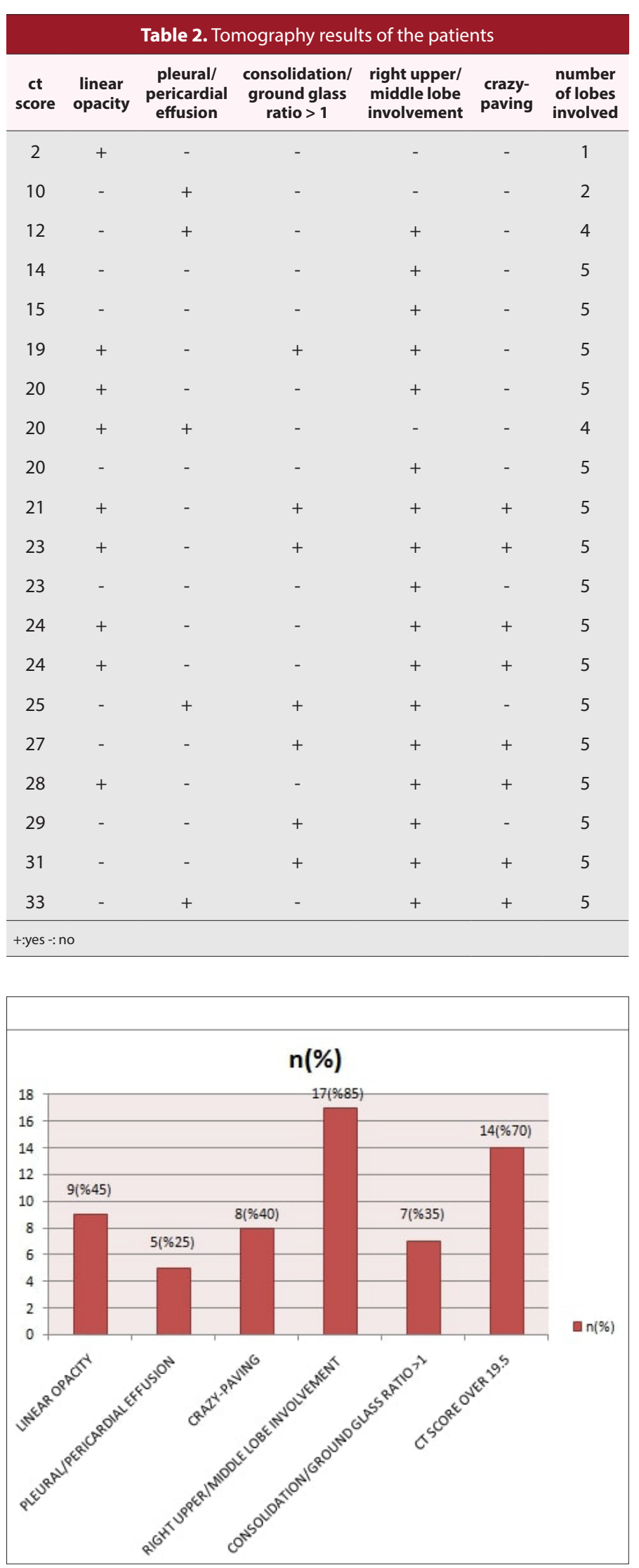

Figure 2. Lineer opacity-Pleural/perdicardial effusion-Crazy-paving-upper and middle lobe involvement of the right lung-consolidation/ground glass ratio $>1$ -CT score over 19.5 
In statistical analysis of 28-day mortality, although all of the bad prognosis results on chest CT do not create a statistically significant difference; consolidation/ground glass ratio $>1$ was found to be approximately five times more mortal.

As in the statistical analysis of all findings of bad prognosis on chest CT in terms of mortality, the statistical analyses of these results did not have a significant difference in the statistical analyses of the duration of intensive care unit stays of critical COVID-19 patients. However, we reported that patients with crazy-paving pattern on their chest $\mathrm{CT}$ had a longer stay in the intensive care unit [patients with intensive care unit stay longer than 7 days $n=12$, patients with crazy-paving pattern $\mathrm{n}=7$ (58.3\%)] (Table 3).

There was no statistically significant correlation between APACHE II scores and their poor prognosis findings on chest CT of the COVID-19 patients followed up in the ICU (Figure 3)

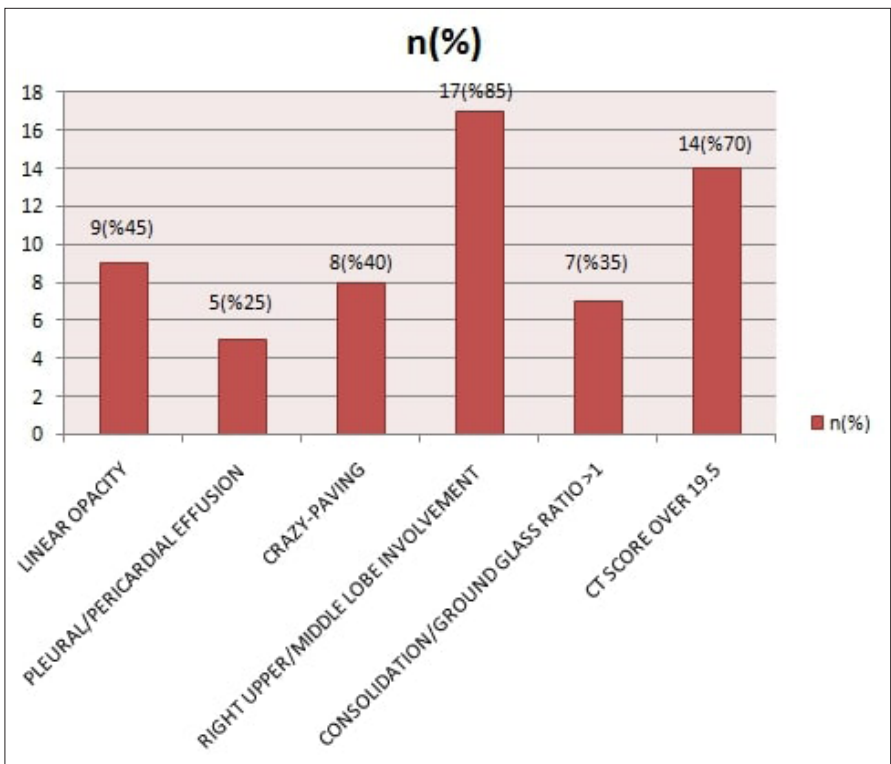

Figure 2. Lineer opacity-Pleural/perdicardial effusion-Crazy-paving-upper and middle lobe involvement of the right lung-consolidation/ground glass ratio $>1$ -CT score over 19.5

\section{DISCUSSION}

In the current study, we intended to answer the question "Can we have a preliminary information about the intensive care process of COVID-19 patients based on their chest CT scans performed prior to their admission to intensive care unit? ".

COVID-19 disease is more common in the male population. In a meta-analysis by Li et al. ${ }^{[17]}, 60 \%$ of people suffering from COVID-19 are men. The male population rate was $80 \%(n=16)$ in the present study and the male population was dominant.

The overall mortality rate of COVID-19 disease as of $25^{\text {th }}$ August was $2.36 \%$ in general society in Turkey. ${ }^{[18]}$ However, we know that mortality rate is higher in patients admitted to intensive care. In the study of Pavan et al., the mortality rate of critical COVID-19 patients is 50\%. ${ }^{[19]}$ In the present study, our mortality rate was $55 \%$ (n: 11$)$, which is somewhat similar to the study by Pavan et al.

Critical COVID-19 patients require invasive mechanical ventilator support during intensive care follow-up. In our study, 14 patients (70\%) were administered invasive mechanical ventilator support. In a study by Yang et al., including 52 critical COVID-19 patients, 37 patients (71\%) required invasive mechanical ventilator support. ${ }^{[20]}$

In COVID-19, chest CT was used to support the diagnosis of the disease in general and to determine the severity of the disease. ${ }^{[6,21]}$ However, clinical and laboratory data are used for its prognosis. ${ }^{[22,23]}$ There are still limited number of studies in the literature, which report that the chest CT findings can provide information about the prognosis of COVID-19 patients. In a study by Liu et al. ${ }^{[24]}$, early thoracic findings were reported to provide information about the prognosis of the disease.

In existing studies, certain chest CT findings were correlated with the severity of the disease. ${ }^{[13,14]}$ In a study by Yang et al. ${ }^{[13]}$, intended to determine the severe COVID-19 disease, it is stated that a CT score of $>19.5$ could be used to identify patients in critical condition. Note that the CT score may reveal the severity of the disease; however, according to the result in our

Table 3. Statistical analysis of all findings of bad prognosis on chest CT

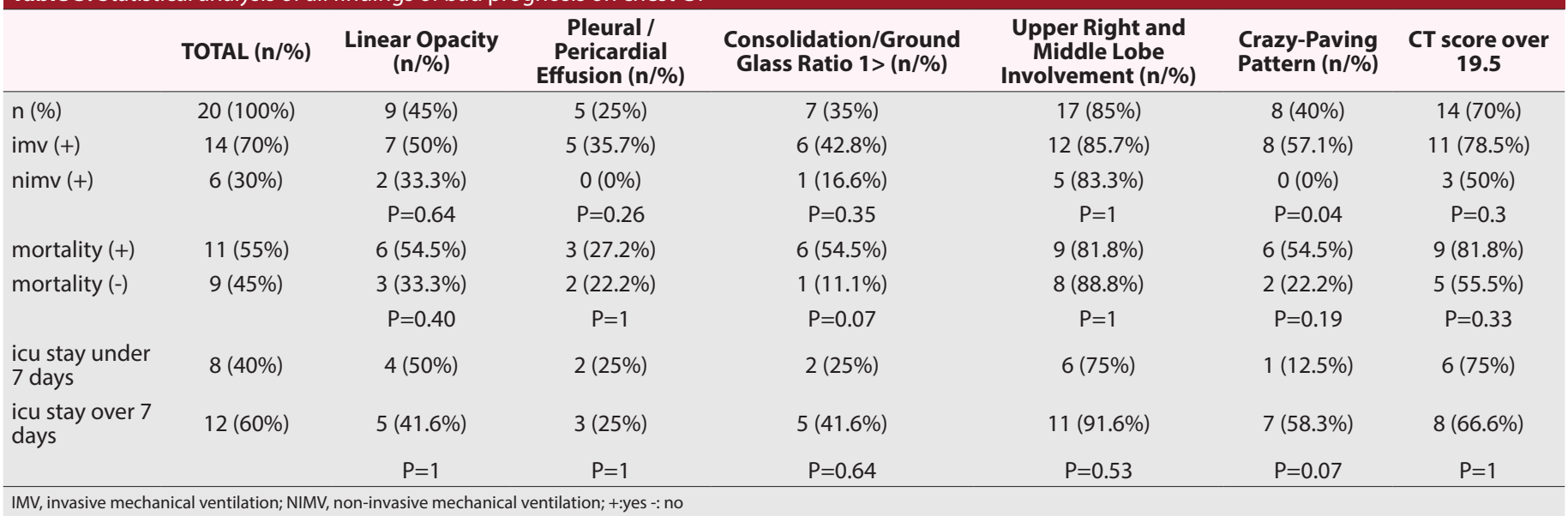


study, CT score is not predictive of 28-day mortality, duration of intensive care stay, and invasive mechanic ventilator support in the critical COVID-19 patients.

Note that the presence of ground glass pattern in chest CT was considered a typical diagnostic image of COVID-19 disease. ${ }^{[25]}$ Moreover, the presence of consolidation of the lungs agrees more with the severity of the disease. ${ }^{[2]}$ As a result of our study, we reported that high consolidation in the chest CT (consolidation/ground glass ratio $>1$ ) increased mortality in critical Covid patients by five times.

In the study by Peijie et al. ${ }^{[24]}$, it was found that presence of crazy-paving pattern on the chest CT images of critical COVID-19 patients is correlated with the severity of the disease. Moreover, our study demonstrated that the presence of crazypaving pattern on chest $C T$ was statistically correlated with the requirement for invasive mechanical ventilator support of the critical COVID-19 patients during their intensive care unit stay (p:0.04). Although the crazy-paving pattern does not make a statistically significant difference in the duration of intensive care stay, there was chest CT finding present in $>50 \%$ of the patients with intensive care stay of $>7$ days $(n=7,58 \%)$.

Pleural/pericardial effusion is more common in critical COVID-19 patients compared to normal COVID-19 patients. ${ }^{[6]}$ In our study, we reported that all of the patients with pleural/ pericardial effusion required invasive mechanical ventilator support.

We believe that linear opacity and upper right/middle lobe involvement, which are chest CT results of critical COVID-19 patients in certain studies, ${ }^{[6,16]}$ do not provide an insight into the prognosis of critical COVID-19 patients during the intensive care process.

APACHE II score is a commonly used scale to predict mortality in critical patients.[26] In our study, we reported that the results that we consider bad prognosis on chest $C T$ are not correlated with APACHE II scores of the critical COVID-19 patients.

Because of the small number of patients, there are relative limitations in our study. To reveal the relation between chest CT and prognosis, additional studies with more participants are required.

\section{CONCLUSION}

Clinical and laboratory data were primarily used as prognostic factors in COVID-19 patients. With this study, we believe that radiological imaging can help predict the prognosis and support for diagnosing critical COVID-19 patients.

\section{ETHICAL DECLARATIONS}

Ethics Committee Approval: Ethics committee approval for the study was received from the Non-Invasive Clinical Research Ethics Committee of Zonguldak Bülent Ecevit University on 25 June 2020, with the decision numbered 2020/14.
Informed Consent: Because the study was designed retrospectively, no written informed consent form was obtained from patients

Referee Evaluation Process: Externally peer-reviewed.

Conflict of Interest Statement: The author(s) declared no potential conflicts of interest with respect to the research, authorship, and/or publication of this article.

Financial Disclosure: The authors declared that this study has received no financial support.

\section{REFERENCES}

1. Huang C, Wang Y, Li X, et al. Clinical features of patients infected with 2019 novel coronavirus in Wuhan, China. Lancet. 2020;395(10223):497-506. doi:10.1016/S0140-6736(20)30183-5

2. Zhu N, Zhang D, Wang W, et al. A Novel Coronavirus from Patients with Pneumonia in China, 2019. N Engl J Med. 2020;382(8):727-733. doi:10.1056/NEJMoa2001017

3. https://www.who.int/docs/default-source/coronaviruse/situationreports/20200211-sitrep-22-ncov.pdf?sfvrsn=fb6d49b1

4. Shang $Y, X u C$, Jiang $F$, et al. Clinical characteristics and changes of chest CT features in 307 patients with common COVID-19 pneumonia infected SARS-CoV-2: A multicenter study in Jiangsu, China. Int J Infect Dis. 2020;96:157-162. doi:10.1016/j.ijid.2020.05.006

5. Lee $N$, Hui $D, W u A$, et al. A major outbreak of severe acute respiratory syndrome in Hong Kong. N Engl J Med. 2003;348(20):1986-1994. doi:10.1056/NEJMoa030685

6. Li K, Wu J, Wu F, et al. The Clinical and Chest CT Features Associated With Severe and Critical COVID-19 Pneumonia. Invest Radiol. 2020;55(6):327331. doi:10.1097/RLI.0000000000000672

7. Tan W. J, Zhao X., Ma X. et al. A novel coronavirus genome identified in a cluster of pneumonia cases-Wuhan, China 2019- 2020. China CDC Weekly 2020; 2 (4): 61-2. doi: 10.46234/ccdcw2020.017

8. Chan JF, Yip CC, To KK, et al. Improved Molecular Diagnosis of COVID-19 by the Novel, Highly Sensitive and Specific COVID-19-RdRp/Hel RealTime Reverse Transcription-PCR Assay Validated In Vitro and with Clinical Specimens. J Clin Microbiol. 2020;58(5):e00310-20. doi:10.1128/ JCM.00310-20

9. Wang $\mathrm{Y}$, Hou H, Wang W, Wang W. Combination of CT and RT-PCR in the screening or diagnosis of COVID-19. J Glob Health. 2020;10(1):010347. doi:10.7189/jogh.10.010347

10. Chung M, Bernheim A, Mei X, et al. CT Imaging Features of 2019 Novel Coronavirus (2019-nCoV). Radiology. 2020;295(1):202-207. doi:10.1148/ radiol.2020200230

11. Li X, Zeng X, Liu B, et al. COVID-19 infection presenting with CT halo sign. Radiology: Cardiothoracic Imaging, 2(1), doi: 10.1148/ ryct.2020200026

12. Ai T, Yang $\mathrm{Z}$, Hou $\mathrm{H}$, et al. Correlation of Chest CT and RT-PCR Testing for Coronavirus Disease 2019 (COVID-19) in China: A Report of 1014 Cases. Radiology. 2020;296(2):E32-E40. doi:10.1148/radiol.2020200642

13. Yang R, Li X, Liu H et all (2020) Chest CT Severity Score: An Imaging Tool for Assessing Severe COVID-19 Radiology: Cardiothoracic Imaging, 2(2) doi:10.1148/ryct.2020200047

14. Lyu P, Liu X, Zhang R,et al. The Performance of Chest CT in Evaluating the Clinical Severity of COVID-19 Pneumonia: Identifying Critical Cases Based on CT Characteristics. Invest Radiol. 2020;55(7):412-421. doi:10.1097/ RLI.0000000000000689

15. Xiong Y, Sun D, Liu Y, et al. Clinical and High-Resolution CT Features of the COVID-19 Infection: Comparison of the Initial and Followup Changes. Invest Radiol. 2020;55(6):332-339. doi:10.1097/ RLI.0000000000000674 
16. Li K, Fang Y, Li W, et al. CT image visual quantitative evaluation and clinical classification of coronavirus disease (COVID-19). Eur Radiol. 2020;30(8):4407-4416. doi:10.1007/s00330-020-06817-6

17. Li LQ, Huang T, Wang YQ, et al. COVID-19 patients' clinical characteristics, discharge rate, and fatality rate of meta-analysis. J Med Virol. 2020;92(6):577-583. doi:10.1002/jmv.25757

18. https://covid19.saglik.gov.tr/TR-66935/genel-koronavirus-tablosu.html

19. Bhatraju PK, Ghassemieh BJ, Nichols M, et al. Covid-19 in Critically III Patients in the Seattle Region - Case Series. N Engl J Med. 2020;382(21):2012-2022. doi:10.1056/NEJMoa2004500

20. Yang $X, Y u Y, X u J$, et al. Clinical course and outcomes of critically ill patients with SARS-CoV-2 pneumonia in Wuhan, China: a single-centered, retrospective, observational study. Lancet Respir Med. 2020;8(5):475-481. doi:10.1016/S2213-2600(20)30079-5

21. Li Y, Xia L. Coronavirus Disease 2019 (COVID-19): Role of Chest CT in Diagnosis and Management. AJR Am J Roentgenol. 2020;214(6):12801286. doi:10.2214/AJR.20.22954

22. Frater JL, Zini G, d'Onofrio G, et al. COVID-19 and the clinical hematology laboratory. Int J Lab Hematol. 2020;42 Suppl 1:11-18. doi:10.1111/ ijlh.13229

23. Pan F, Yang L, Li Y, et al. Factors associated with death outcome in patients with severe coronavirus disease-19 (COVID-19): a case-control study. Int J Med Sci. 2020;17(9):1281-1292. doi:10.7150/ijms.46614

24. Liu F, Zhang Q, Huang C, et al. CT quantification of pneumonia lesions in early days predicts progression to severe illness in a cohort of COVID-19 patients. Theranostics. 2020;10(12):5613-5622. doi:10.7150/thno.45985

25. Salehi S, Abedi A, Balakrishnan S, Gholamrezanezhad A. Coronavirus Disease 2019 (COVID-19): A Systematic Review of Imaging Findings in 919 Patients. AJR Am J Roentgenol. 2020;215(1):87-93. doi:10.2214/ AJR.20.23034

26. Knaus WA, Draper EA, Wagner DP, et al. APACHE II: a severity of disease classification system. Crit Care Med. 1985;13(10):818-829. doi: 10.1097/00003465-198603000-00013 